\title{
Selection of CTV-tolerant citrus hybrids for ornamental use
}

\author{
Alanna Rachel Andrade dos Santos ${ }^{1}$, Everton Hilo de Souza ${ }^{2, \star}$, Michaella Fadini ${ }^{1}$, Fernanda Vidigal \\ Duarte Souza $^{3}$, Cristiane de Jesus Barbosa ${ }^{3}$, Eduardo Augusto Girardi ${ }^{3}$ and Walter dos Santos Soares \\ Filho $^{3, \star \star}$ \\ 1 Federal University of Recôncavo of Bahia, Cruz das Almas, Bahia, Brazil \\ 2 CAPES/ Embrapa Cassava \& Fruits Cruz das Almas, Bahia, Brazil \\ 3 Embrapa Cassava \& Fruits, Cruz das Almas, Bahia, Brazil
}

Received 2 March 2016 - Accepted 4 July 2016

\begin{abstract}
Introduction. Ornamental citrus is well established in Europe and North America, but is still incipient in Brazil, despite the fact that the country is among the world's leading citrus fruit producers. However, the potential for innovation in this agribusiness segment is increasingly recognized. The Citrus Breeding Program of Embrapa Cassava \& Fruits, among other objectives, aims to create plants suitable for ornamental use. Materials and methods. Ten hybrids were characterized by application of 39 morphological descriptors to identify their ornamental potential and to classify them in use categories. Additionally, these hybrids were evaluated regarding their susceptibility to the citrus tristeza virus $(\mathrm{CTV})$. Results and discussion. The hybrids [(RPL x YMCT-005) $\times$ MCP-011], [(RPL $\times$ YMCT-005) $\times$ MCP-015], [GLINL $\times$ MCP-002], [GLINL $\times$ FTNL-001], [RPL $\times$ MCSH-002] and [CSM $\times$ MCP-002] can be recommended for use as potted plants, minifruit, landscaping and hedges; [(RPL $\times$ YMCT-005) $\times$ MCP-016], [CSM $\times$ MCP-003] are suitable as potted plants, landscaping and hedges; [(RPL $\times$ YMCT-005) $\times$ SMM-014] fits in the potted plant, landscaping and ornamental minifruit; and [ $(\mathrm{RPL} \times$ YMCT-005) $\times$ GLINL-001] is suitable for use as potted plants and in landscaping. According to the results on the reaction to the CVT pathogen, four hybrids were classified as resistant, four were classified as highly tolerant and two were classified as highly intolerant, indicating the need for their protection with weak CTV strains Conclusion. The hybrids evaluated presented substantial morphological variability that distinguished them from each other. Their traits qualify them for use as ornamental plants.
\end{abstract}

Keywords: Brazil / Citrus spp. / citrus tristeza virus / landscaping / minifruit / species selection

Résumé - Sélection d'hybrides d'agrumes tolérants au CVT à fin d'ornement. Introduction. La production d'agrumes ornementaux, bien établie en Europe et en Amérique du Nord, en est encore à ses débuts au Brésil, en dépit du fait que le pays figure parmi les principaux producteurs d'agrumes au monde. Cependant, le potentiel d'innovation dans ce segment de l'agro-industrie est de plus en plus reconnu. Le programme de sélection d'agrumes de la division Manioc \& Fruits de l'Embrapa vise à créer, entre autres, des plantes adaptées à des fins ornementales. Matériel et méthodes. Dix hybrides ont été caractérisés par application de 39 descripteurs morphologiques, dans le but d'identifier leur potentiel ornemental et de les classer par catégorie d'utilisation. En outre, ces hybrides ont été évalués quant à leur sensibilité au virus de la Tristeza des agrumes $(\mathrm{CTV})$. Résultats et discussion. Les hybrides $[(\mathrm{RPL} \times \mathrm{YMCT}-005) \times$ MCP-011], [(RPL $\times$ YMCT-005 $) \times$ MCP-015], [GLINL $\times$ MCP-002], [GLINL $\times$ FTNL-001], $[$ RPL $\times$ MCSH -002$]$ et $[\mathrm{CSM} \times \mathrm{MCP}-002]$ peuvent être recommandés pour une utilisation en tant que plantes en pot, pour la production de mini fruits, l'aménagement paysager et les haies ; [(RPL $\times$ YMCT-005) × MCP-016] et [CSM × MCP-003] conviendraient plutôt comme plantes en pot, pour l'aménagement paysager et les haies ; [(RPL $\times$ YMCT-005) $\times$ SMM-014] conviendrait comme plante en pot, en aménagement paysager et production de mini fruits ornementaux ; et $[(\mathrm{RPL} \times$ YMCT-005) $\times$ GLINL-001] est adapté à une utilisation en plantes en pot et en aménagement paysager. Selon leur sensibilité au CVT, quatre hybrides ont été classés comme résistants, quatre ont été classés comme très tolérants et deux ont été classés comme très intolérants, ce qui indique la nécessité d'une protection par des souches de CTV atténuées. Conclusion. Les hybrides évalués présentent une variabilité morphologique importante qui les distingue les uns des autres. Leurs caractéristiques les qualifient comme plantes ornementales.

Mots clés : Brésil / Citrus spp. / virus de la tristeza des agrumes / aménagement paysager / mini fruits / sélection variétale

\footnotetext{
^ Corresponding author: hilosouza@gmail.com

$\star \star$ Corresponding author: walter.soares@embrapa.br
} 


\section{Introduction}

Citrus growing is an important economic activity in Brazil and the rest of the world, not only for the high value of the fruits produced, but also the large number of direct and indirect jobs generated. In 2013, global citrus fruit output reached $1,378 \mathrm{Mt}$, of this $53 \%$ being sweet oranges (Citrus sinensis (L.) Osbeck). Brazil stands out as a producer of citrus, with output of $197 \mathrm{Mt}$, mostly consisting of sweet oranges, making citrus the leading fruit growing segment in the country [1].

The genus Citrus L. belongs to the family Rutaceae and together with Poncirus L., Fortunella Swingle, Microcitrus Swingle and Eremocitrus Swingle forms the true citrus group, because of bearing fruits similar to the sweet orange or lemon [2].

The genetic variability of these genera is extensive, notably in Citrus, enabling obtaining new varieties, rootstocks and scions with the ability to promote sustainability of the citrus agribusiness, not only for production of fruits for food, but also for other purposes, such as making drugs, cosmetics and perfumes [3-5]. Additionally, because of the beauty and originality of plant shapes, they are increasingly being used for ornamental purposes [6-8].

Floriculture generates revenues of US\$ 107 billion annually and has a great capacity to create employment and income, mainly for small-scale farmers [9]. In addition to this social aspect, the activity is also important for keeping people in the field. Thus, the ornamental citrus production emerges as an activity that can add social and economic value to the conventional citrus production.

Landscapers and gardeners are always in search of new innovations. In this context, tropical and subtropical fruitbearing plants have great potential for ornamental use, in competition with traditional plants from temperate climates [1]. Among these fruiting plants, citrus species are highly attractive due to their pleasant-smelling flowers and fruits with varied sizes, shapes and colors. Depending on the variety, citrus plants can produce over almost the entire year.

In Brazil, research to obtain citrus varieties with ornamental potential, although still scant, has been intensifying in recent years. In this respect, the Citrus Breeding Program of Embrapa Cassava \& Fruits (CBP) started developing hybrids for this purpose, based on the genetic variability existing in the Citrus Active Germplasm Bank of Embrapa Cassava \& Fruits (CAGB), which contains more than 750 accessions [8], the most diversified in the world in tropical regions. This diversity supports the identification of promising varieties for ornamental uses and the creation of hybrids for this purpose.

Accessions of the CAGB have been crossed for the past five years aiming to develop hybrid varieties suitable as ornamental plants. Among the species of Citrus and related genera involved in this cross-breeding are: $C$. amblycarpa (Hassk.) Ochse, $C$. aurantiifolia (Christm.) Swingle, C. medica L., C. depressa Hayata, C. sunki (Hayata) hort. ex Tanaka, C. sinensis, C. jambhiri Lush., C. limonia Osbeck, C. myrtifolia Raf., C. madurensis auct, C. webberi Wester var. montana Wester, C. maxima (Burm.) Merr., Poncirus trifoliata (L.) Raf., Fortunella spp. and Microcitrus spp. The results of this hybridization program have been promising.
However, for citrus to become established in the ornamental plant market, besides having attributes valued by consumers, promising individuals must be selected considering a wide range of assessments, including phytosanitary considerations. Among the diseases that affect these plants, that caused by the citrus tristeza virus (CTV) stands out. This virus is transmitted by aphids mainly the brown citrus aphid (Toxoptera citricida Kirkaldy), and contaminated propagation materials [11]. Considerable harm is done by some strains of this pathogen, inducing stem pitting and visible grooves in the branches and trunk, impairing the plant's vigor and diminishing the productivity and size of fruits from intolerant scions. The disease's advance can cause collapse of the phloem and root structure, killing the plant $[12,13]$. The most effective way to control the disease is the use of resistant or tolerant varieties and pre-immunization with mild strains of the virus Therefore, knowledge on this virus tolerance is critical for the selection of new ornamental citrus hybrids.

Therefore, the aim of this study was to characterize and evaluate hybrid seedlings from the crosses carried out by the CBP to identify individuals with ornamental potential and to classify them in use categories, as potted plants, hedges, for landscaping or production of miniature fruit. The hybrids were also assessed in relation to CTV resistance.

\section{Material and methods}

\subsection{Experimental design and plant materials}

The study was conducted in an open area of the experimental farm of the CBP, located in the municipality of Cruz das Almas, Bahia, Brazil (12 $40^{\prime} 19^{\prime \prime}$ S latitude and $39^{\circ} 06^{\prime} 22^{\prime \prime}$ W longitude, $220 \mathrm{~m}$ altitude).

According to the Köppen classification, the climate in Cruz das Almas is a transition between the Am and Aw zones, with average annual rainfall of $1,143 \mathrm{~mm}$, average temperature of $24.4{ }^{\circ} \mathrm{C}$ and relative humidity of $81 \%$. The soil of the experimental area is a typical dystrophic Yellow Latosol, a moderate, sandy clay loam texture, kaolinite, hypoferric, transition zone between sub-perennial and semi-deciduous rainforest, with slope of $0-3 \%$.

Ten hybrid seedlings were evaluated:

RYM011 $=[($ RPL $\times$ YMCT-005 $) \times$ MCP-011 $]$,

RYM015 $=[($ RPL $\times$ YMCT-005 $) \times$ MCP-015 $]$,

RYM016 $=[($ RPL $\times$ YMCT-005 $) \times$ MCP-016 $]$,

GM002 $=[$ GLINL $\times$ MCP-002 $]$,

GF001 $=[$ GLINL $\times$ FTNL-001]

RYG001 $=[($ RPL $\times$ YMCT-005 $) \times$ GLINL-001 $]$,

$\mathrm{CM} 002=[\mathrm{CSM} \times \mathrm{MCP}-002]$,

$\mathrm{CM} 003=[\mathrm{CSM} \times \mathrm{MCP}-003]$,

RYS014 $=[($ RPL $\times$ YMCT-005 $) \times$ SMM-014 $]$, and

RM002 $=[$ RPL $\times$ MCSH-002 $]$. 
In the latter case, the seeds came from a 12 year old plant, while in the other cases the parental plants were 3 to 4 years old. The abbreviations used here are: RPL = 'Rangpur' lime (C. limonia), YMCT $=$ 'Yuma' citrange $(C$. sinensis $\times$ P. trifoliata), $\mathrm{MCP}=$ M. papuana Winters, GLINL = 'Galego Inerme Key' lime (C. aurantiifolia $), \mathrm{FTNL}=$ Fortunella, $\mathrm{CSM}=\mathrm{com}-$ mon 'Sunki' mandarin (C. sunki), $\mathrm{SMM}=$ 'Sunki Maravilha' mandarin, and MCSH = Microcitrus Sydney hybrid, a hybrid from crossing $M$. australis (A. Cunn. ex Mudie) Swingle $\times M$. australasica (F. Muell.) Swingle.

\subsection{Morphological descriptors}

The morphology of these hybrids and their parentage was characterized using a list of adjusted morphological descriptors from the Descriptors for Citrus list of the International Plant Genetic Resources Institute [14], according to the needs of this work. A total of 39 descriptors were used, 11 quantitative and 28 qualitative. Of the quantitative descriptors, three were related to plant traits [plant height (PLH), trunk diameter (TRD) and crown diameter (CRD)], four to leaf traits [leaf length (LFL), leaf width (LFW), phyllode length (PHL) and phyllode width (PHW)], and four to fruit traits [fruit length (FRL), fruit diameter (FRD), number of fruits per bunch (NFB) and average number of fruits per bunch (AFB)]. In turn, of the qualitative descriptors, five referred to attributes of the plants [crown shape (CRS), branch density (DRB), spine density (SPD), spine length (SPC) and spine shape (SPS)], nine to leaf aspects [leaf division (LFD), leaf variegation (LVA), leaf color (LCO), leaf lamina insertion (LLI), leaf lamina shape (LLS), leaf lamina margin (LLM), leaf apex (LAP), phyllode (PHY) and phyllode shape (PHS)], nine to fruit appearance [fruit shape (FRS), shape of fruit base (FSB), shape of fruit apex (FSA), fruit variegation (FRV), immature fruit color (IFC), ripe fruit color (RFC), fruit surface texture (FST), albedo color (ALC) and pulp color (PUC)], and five to flower traits [color of open flowers (COF), arrangement of flowers (AFL), position of flower or inflorescence (PFI), aroma (ARO) and aroma persistence (ARP)]. The colors were compared with the color chart of the Royal Horticulture Society (RHS). In relation to the leaf descriptors, an average was obtained by observing 20 completely expanded and mature leaves, located in the middle third of the youngest branches from spring growth that did not show signs of active growth. The flowers and fruits were characterized based on 20 replications, with the flowers observed on terminal branches at the time of full flowering and the fruits at the harvest point, located on the periphery of the crown

The traits considered for classification of the hybrids in different categories for ornamental use followed the method described by Santos et al. [8], as summarized below:

- Potted plants: Plant height below $170 \mathrm{~cm}$, crown diameter smaller than $150 \mathrm{~cm}$, moderate or dense branching, preferably with few or no spines. Accessions with larger height and crown diameter could be considered, if associated with dwarf rootstocks or plants manageable by topiary to keep them small.
- Minifruit plants: Fruit diameter (or length for elongated fruits) varying from $2.5 \mathrm{~cm}$ to $4.5 \mathrm{~cm}$.

- Hedge plants: Dense branching.

- Landscaping plants: Broad category, possibly including potted plant, minifruit and hedges. One desirable common feature of plants in this category is absence or low density of spines.

\subsection{Virus testing}

The assessment of susceptibility of the hybrids to CTV was carried out in two steps. Initially, the presence and severity of disease symptoms were evaluated on the branches. Ten branches, $20 \mathrm{~cm}$ long, were removed from each quadrant of the plant. These branches were autoclaved for $10 \mathrm{~min}$ to facilitate removal of the bark, after which they were evaluated by three examiners, using the scoring scale described by Meissner Filho et al. [15], where $1=$ absence of grooves, $2=$ presence of sparse grooves, $3=$ intermediate number of grooves, $4=$ more numerous superficial grooves and/or a few deep grooves; and $5=$ entire surface of the branch covered with superficial and/or deep grooves. Then the sample branches were analyzed by the indirect ELISA test [16], utilizing the polyclonal antiserum against CTV. As negative control, bark samples from branches of $P$. trifoliata were used, while the positive control consisted of samples from $C$. aurantiifolia. Ten replications were employed for the negative control and three for the positive control. The absorbance was read by using ELISA plates (Elx 800 Universal Microplate Reader), after reaction for 10 min with the substrate buffer $\left(0.87 \mathrm{mg} \mathrm{L}^{-1}\right.$ p-nitrophenyl phosphate). To determine the absorbance limit value, which allows diagnosing infected and healthy samples, the mean of the negative control plus the standard deviation in each test was used

Based on the results on the presence and severity of grooves and the ELISA test, the hybrids were classified regarding susceptibility to the CTV, as: resistant (absence of virus in tissues and no grooves on branches), very tolerant (presence of virus in tissues but absence of grooves on branches), tolerant (maximum score of 2), intolerant (maximum score of 3), very intolerant (maximum score of 4 ), and extremely intolerant (maximum score of 5).

\section{Results and discussion}

\subsection{Morphological characterization}

A wide phenotypic variability was observed, even between individuals with one or both parents in common. The variability was most evident in the fruits and leaves, which presented considerable diversity of shapes, sizes and colors (tables I-IV; figure 1).

Among the hybrids selected, three came from crosses of [RPL $\times$ YMCT-005] (female parental) and MCP: RYM011, RYM015 and RYM016 (figures $1 a-1 d$ ).

The hybrid RYM011 (figure 1a) has medium size (height of $230 \mathrm{~cm}$ ). Its crown is ellipsoid and considerably dense, with a large number of small spines (table I). Although the presence 
Table I. Morphological traits of 10 hybrid citrus seedlings with potential for ornamental use and their parentals. Values for quantitative descriptors are the mean of 3 replications followed by the standard errors.

\begin{tabular}{|c|c|c|c|c|c|c|c|c|}
\hline Hybrids & PLH & TRD & CRD & CRS & DRB & SPD & SPC & SPS \\
\hline RYM011 & $230.0 \pm 12.5$ & $7.0 \pm 1.2$ & $180.0 \pm 10.2$ & ELI & DEN & HIG & $6-15 \mathrm{~mm}$ & STR \\
\hline RYM015 & $184.0 \pm 10.3$ & $7.5 \pm 0.8$ & $160.0 \pm 8.7$ & ELI & DEN & HIG & $6-15 \mathrm{~mm}$ & STR \\
\hline RYM016 & $170.0 \pm 8.7$ & $4.3 \pm 0.5$ & $150.0 \pm 9.2$ & OVO & DEN & HIG & $6-15 \mathrm{~mm}$ & STR \\
\hline GM002 & $230.0 \pm 14.3$ & $7.2 \pm 1.0$ & $200.0 \pm 11.2$ & ELI & DEN & HIG & $6-15 \mathrm{~mm}$ & STR \\
\hline GF001 & $190.0 \pm 6.3$ & $7.6 \pm 1.1$ & $135.0 \pm 7.2$ & ELI & DEN & HIG & $6-15 \mathrm{~mm}$ & STR \\
\hline RYG001 & $160.0 \pm 4.4$ & $7.9 \pm 0.9$ & $148.0 \pm 5.2$ & SPH & DEN & HIG & $6-15 \mathrm{~mm}$ & STR \\
\hline RM002 & $150.0 \pm 3.5$ & $6.3 \pm 0.8$ & $141.0 \pm 4.3$ & SPH & DEN & HIG & $<5 \mathrm{~mm}$ & STR \\
\hline CM002 & $337.0 \pm 11.3$ & $7.9 \pm 0.5$ & $239.0 \pm 12.7$ & ELI & DEN & HIG & $16-40 \mathrm{~mm}$ & STR \\
\hline CM003 & $247.0 \pm 9.3$ & $6.7 \pm 0.7$ & $185.0 \pm 6.8$ & ELI & DEN & HIG & $16-40 \mathrm{~mm}$ & STR \\
\hline RYS014 & $222.0 \pm 8.7$ & $8.8 \pm 1.2$ & $292.0 \pm 9.2$ & SPH & DEN & MED & $16-40 \mathrm{~mm}$ & STR \\
\hline Parentals & PLH & TRD & CRD & CRS & DRB & SPD & SPC & SPS \\
\hline RY005 & $279.0 \pm 12.5$ & $11.0 \pm 1.0$ & $339.0 \pm 41.3$ & OVO & MED & $\mathrm{ABS}$ & $\mathrm{ABS}$ & $\mathrm{ABS}$ \\
\hline $\mathrm{MCP}$ & $140.0 \pm 8.12$ & $3.0 \pm 0.3$ & $85.0 \pm 8.3$ & ELI & DEN & HIG & $6-15 \mathrm{~mm}$ & STR \\
\hline GLINL & $330.0 \pm 22.3$ & $11.2 \pm 0.9$ & $540.0 \pm 68.1$ & OVO & DEN & MED & $<5 \mathrm{~mm}$ & STR \\
\hline FTNL & $235.0 \pm 12.3$ & $6.6 \pm 0.8$ & $140.0 \pm 10.7$ & ELI & MED & $\mathrm{ESC}$ & $6-15 \mathrm{~mm}$ & STR \\
\hline RPL & $325.0 \pm 21.2$ & $12.3 \pm 0.7$ & $332.0 \pm 32.8$ & OVO & DEN & ABS & $\mathrm{ABS}$ & ABS \\
\hline CSM & $375.0 \pm 52.3$ & $11.2 \pm 0.9$ & $445.0 \pm 42.3$ & SPH & DEN & ABS & ABS & ABS \\
\hline SMM & $394.0 \pm 62.1$ & $13.0 \pm 1.1$ & $450.0 \pm 61.9$ & OVO & DEN & ABS & ABS & ABS \\
\hline $\mathrm{MCSH}$ & $155.0 \pm 32.2$ & $3.3 \pm 0.3$ & $73.0 \pm 23.3$ & ELI & DEN & HIG & $6-15 \mathrm{~mm}$ & STR \\
\hline
\end{tabular}

$\mathrm{PLH}=$ plant height $(\mathrm{cm}) ; \mathrm{TRD}=$ trunk diameter $(\mathrm{cm}) ; \mathrm{CRD}=$ crown diameter $(\mathrm{cm}) ; \mathrm{CRS}=$ crown shape; DRB = density of branches; SPD = spine density $; \mathrm{SPC}=$ spine length; $\mathrm{SPS}=$ spine shape; $\mathrm{OVO}=$ ovoid $; \mathrm{ELI}=$ ellipsoid SPH = spheroid; DEN = dense; MED = medium; $\mathrm{ABS}=$ absent; HIG = high; STR = straight; RYM011 = (RPL $\times$ YMCT- 005 $) \times$ MCP-011; RYM015 $=($ RPL $\times$ YMCT-005 $) \times$ MCP-015; RYM016 $=($ RPL $x$ YMCT-005 $) \times$ MCP-016; GM002 = GLINL $\times$ MCP-002; GF001 $=$ GLINL $\times$ FTNL-001; RYG001 $=($ RPL $\times$ YMCT-005 $)$ $\times$ GLINL-001; RM002 = RPL $\times$ MCSH 002; CM002 = CSM $\times$ MCP-002; CM003 = CSM $\times$ MCP-003; RYS014 = $($ RPL $\times$ YMCT-005 $)$ $\times$ SMM-014; RY005 = RPL $\times$ YMCT-005; MCP = Microcitrus papuana Winters; GLINL = 'Galego Inerme Key' lime [Citrus aurantiifolia (Christm.) Swingle]; FTNL = Fortunella sp.; RPL= 'Rangpur' lime (C. limonia Osbeck); CSM = common 'Sunki' mandarin [C. sunki (Hayata) hort. ex Tanaka]; SMM = 'Sunki Maravilha' mandarin; YMCT = 'Yuma' citrange [C. sinensis (L.) Osbeck $\times$ Poncirus trifoliata (L.) Raf.]; MCSH = Microcitrus Sydney hybrid [M. australis (A. Cunn. ex Mudie) Swingle $\times$ M. australasica (F. Muell.) Swingle].

of spines is not a determinant for use as hedges, their existence along with dense crown are good attributes for this category, mainly for the purpose of protection and/or security [8]. The leaves of this hybrid are green and small (average length of 38 $\mathrm{cm}$ and width of $1.5 \mathrm{~cm}$ - table II), the fruits are spherical, like those of the female parent, on average measuring $3.8 \mathrm{~cm}$ in length and $3.6 \mathrm{~cm}$ in diameter, and were judged highly attractive (table III), especially because they are produced in large quantity throughout the year. These traits qualify this genotype for use as potted plants, for production of minifruits and for landscaping.

The hybrid RYM015 (figures $1 b$ and $1 c$ ) has characteristics related to structure similar to those of the previous hybrid. The plants also have medium size, with average height of $184 \mathrm{~cm}$ and dense ellipsoid crown, with a large number of spines on the branches (table I). Hence, it is also appropriate for use as hedges. Its leaves are green, small and elliptical (table II). The fruits are elongated, similar to the male parent, M. papuana. They measure approximately $9.0 \mathrm{~cm}$ long and $3.2 \mathrm{~cm}$ in diameter (table III). This hybrid is also distinct regarding its flowers (table IV), typically with three, four or five petals (figure $1 c-$ detail). All these traits make it suitable as a potted plant, for production of minifruits and for landscaping.
The hybrid RYM016 (figure 1d) has small to medium size, with height of $170 \mathrm{~cm}$. Its crown is very dense and ovoid and its branches have high thorn density (table I). The leaves are very small, measuring only $2.9 \mathrm{~cm}$ in length and $1.5 \mathrm{~cm}$ in diameter. They are obovate and dark green (table II). The fruits are spherical, with a neck at the apex, and measure $3.8 \mathrm{~cm}$ in length and $3.3 \mathrm{~cm}$ in diameter. When mature, they have a pleasing light yellow color (table III), which is an advantage for ornamentation. This hybrid is considered suitable for use as hedges, potted plants, landscaping and production of minifruits.

These three hybrids can be used for ornamental purposes due to their beauty and originality, and also considering their good resistance to the tristeza virus. The crown shape and density are adequate for topiary size control and the fruits are highly attractive besides being produced in large quantities.

It is important to stress that the hybrids were evaluated in the form of seedlings (ungrafted plants), so their height and crown diameter can be reduced by grafting on dwarfing rootstocks. The practice of grafting can also promote faster flowering and consequently fruit production. With respect to spines, if this is considered undesirable, it can be prevented by using buds for propagation taken from branches related to more advanced vegetative generations, i.e., ontogenetically 
Table II. Morphological traits of the leaves of 10 hybrid citrus seedlings with potential for ornamental use and their parentals. Values for quantitative descriptors are the mean of 20 replications followed by the standard errors.

\begin{tabular}{|c|c|c|c|c|c|c|c|c|c|c|c|c|c|}
\hline Hybrids & LFL & LFW & LFD & LVA & LCO & LLI & LLS & LLM & LAP & PHY & PHL & PHW & PHS \\
\hline RYM011 & $3.78 \pm 0.18$ & $1.55 \pm 0.08$ & SIM & ABS & MED & SES & ELP & DEN & ATT & $\mathrm{ABS}$ & ABS & ABS & $\overline{A B S}$ \\
\hline RYM015 & $4.62 \pm 0.16$ & $2.17 \pm 0.10$ & SIM & ABS & MED & SES & OBO & DEN & ATT & ABS & ABS & ABS & ABS \\
\hline RYM016 & $2.89 \pm 0.10$ & $1.53 \pm 0.11$ & SIM & ABS & DAR & SES & OBO & DEN & ATT & PRE & $0.46 \pm 0.05$ & $0.10 \pm 0.03$ & ОВО \\
\hline GM002 & $2.92 \pm 0.12$ & $1.36 \pm 0.09$ & SIM & ABS & MED & SES & ELP & DEN & ATT & ABS & ABS & ABS & ABS \\
\hline GF001 & $3.60 \pm 0.15$ & $1.90 \pm 0.07$ & SIM & ABS & MED & SES & ELP & CRE & ATT & ABS & ABS & ABS & ABS \\
\hline RYG001 & $5.98 \pm 0.28$ & $4.11 \pm 0.15$ & SIM & ABS & LIG & SES & ORB & CRE & ROU & PRE & $0.40 \pm 0.03$ & $0.20 \pm 0.02$ & OBC \\
\hline RM002 & $3.80 \pm 0.23$ & $1.30 \pm 0.06$ & SIM & ABS & DAR & SES & ELP & CRE & ATT & ABS & ABS & ABS & ABS \\
\hline CM002 & $4.40 \pm 0.16$ & $2.80 \pm 0.09$ & SIM & ABS & DAR & SES & ELP & DEN & ATT & PRE & $0.40 \pm 0.02$ & $0.10 \pm 0.02$ & $\mathrm{OBC}$ \\
\hline CM003 & $4.90 \pm 0.19$ & $2.20 \pm 0.10$ & SIM & ABS & DAR & SES & ELP & WAV & ATT & ABS & $\mathrm{ABS}$ & ABS & ABS \\
\hline RYS014 & $10.2 \pm 0.38$ & $3.70 \pm 0.12$ & SIM & ABS & MED & BRE & ELP & WAV & ATT & PRE & $1.20 \pm 0.08$ & $0.30 \pm 0.03$ & OBD \\
\hline Parentals & LFL & LFW & LFD & LVA & LCO & LLI & LLS & LLM & LAP & PHY & PHL & PHW & PHS \\
\hline RY005 & $6.30 \pm 0.20$ & $3.20 \pm 0.18$ & SIM & ABS & MED & BRE & OVA & CRE & ATT & PRE & $1.00 \pm 0.06$ & $0.30 \pm 0.02$ & OBO \\
\hline $\mathrm{MCP}$ & $2.28 \pm 0.10$ & $0.96 \pm 0.08$ & SIM & ABS & MED & SES & OVA & CRE & ATT & ABS & ABS & ABS & ABS \\
\hline GLINL & $9.12 \pm 0.23$ & $4.49 \pm 0.12$ & SIM & ABS & LIG & SES & OVA & WAV & ATT & PRE & $1.09 \pm 0.06$ & $0.36 \pm 0.02$ & OBD \\
\hline FTNL & $8.28 \pm 0.18$ & $2.88 \pm 0.07$ & SIM & ABS & MED & SES & ELP & CRE & $\mathrm{ACM}$ & ABS & ABS & ABS & ABS \\
\hline RPL & $10.10 \pm 0.35$ & $5.70 \pm 0.09$ & SIM & ABS & MED & SES & ELP & CRE & ATT & PRE & $1.00 \pm 0.05$ & $0.40 \pm 0.03$ & OBO \\
\hline CSM & $6.34 \pm 0.18$ & $3.39 \pm 0.10$ & SIM & ABS & DAR & SES & ELP & WAV & ATT & ABS & ABS & $\mathrm{ABS}$ & ABS \\
\hline SMM & $6.81 \pm 0.15$ & $3.00 \pm 0.08$ & SIM & ABS & DAR & SES & OVA & CRE & ATT & ABS & ABS & ABS & ABS \\
\hline MCSH & $2.15 \pm 0.10$ & $0.88 \pm 0.06$ & SIM & ABS & MED & SES & OVA & CRE & ATT & ABS & ABS & ABS & ABS \\
\hline
\end{tabular}

$\mathrm{LFL}=$ leaf length $(\mathrm{cm}) ; \mathrm{LFW}=$ leaf width $(\mathrm{cm}) ; \mathrm{LFD}=$ leaf division; $\mathrm{LVA}=$ leaf variegation; $\mathrm{LCO}=$ leaf color; $\mathrm{LLI}=$ leaf lamina insertion; LLS = leaf lamina shape; LLM = leaf lamina margin; LAP = leaf apex; PHY = phyllode; PHL = phyllode length $(\mathrm{cm}) ;$ PHW = phyllode width $(\mathrm{cm}) ;$ PHS = phyllode shape; SIM = simple; ABS = absent; PRE = present; LIG = light; MED = medium; DAR = dark; SES = sessile; $\mathrm{BRE}=$ brevipetiolate; $\mathrm{ELP}=$ elliptic; $\mathrm{OBO}=$ obovate OVA = ovate; ORB = orbicular; WAV = wavy $\mathrm{CRE}=\mathrm{crenada} ; \mathrm{DEN}=\mathrm{dentada} ; \mathrm{ATT}$ $=$ attenuate; $\mathrm{ROU}=$ rounded $\mathrm{ACM}=$ acuminate $\mathrm{OBO}=$ obovate; $\mathrm{OBD}=$ obdeltate $\mathrm{OBC}=$ obcordate $\mathrm{RYM011}=(\mathrm{RPL} \times \mathrm{YMCT}-005) \times$ MCP- 011, RYM015 = $($ RPL $\times$ YMCT-005 $) \times$ MCP-015, RYM016 $=($ RPL $\times$ YMCT-005 $) \times$ MCP-016, GM002 $=$ GLINL $\times$ MCP-002, GF001 $=$ GLINL $\times$ FTNL-001, RYG001 $=($ RPL $\times$ YMCT-005 $) \times$ GLINL-001, CM002 $=$ CSM $\times$ MCP-002, CM003 = CSM $\times$ MCP-003, RYS014 $=(\mathrm{RPL} \times$ YMCT-005) $\times$ SMM-014 and RM002 $=\mathrm{RPL} \times \mathrm{MCSH} 002 ; \mathrm{MCP}=$ Microcitrus papuana Winters; GLINL $=$ 'Galego Inerme Key' lime [Citrus aurantiifolia (Christm.) Swingle]; FTNL = Fortunella sp.; RPL= 'Rangpur' lime (C. limonia Osbeck); CSM = common 'Sunki' mandarin [C. sunki (Hayata) hort. ex Tanaka]; SMM = 'Sunki Maravilha' mandarin; YMCT = 'Yuma' citrange [C. sinensis $(\mathrm{L}$.) Osbeck $\times$ Poncirus trifoliata (L.) Raf.]; MCSH = Microcitrus Sydney hybrid [M. australis (A. Cunn. ex Mudie) Swingle $\times$ M. australasica (F. Muell.) Swingle].

adult branches, on which spines are very sparse or absent in citrus in general $[17,18]$. Studies of compatibility between varieties for grafting and thorn characteristics need to be carried out to confirm this assertion.

The hybrid GM002 (figure 1e) is the result of crossing GLINL [ 'Galego Inerme Key' lime (C. aurantiifolia)] and M. papuana. It has a height of $230 \mathrm{~cm}$ and a very dense crown with many spines (table I), traits inherited from M. papuana. Its leaves are small, approximately $2.9 \mathrm{~cm}$ long and $1.4 \mathrm{~cm}$ wide (table II), also related to the influence of its parentage of the genus Microcitrus. Its fruits have rough peels and are elongated like those of M. papuana. When ripe, they have a pleasing yellow color (table III), making them adequate to use for producing minifruits. This genotype can also be used to form hedges, as potted plants and for landscaping. As is the case of the 10 other hybrids evaluated, this one can be used as a potted plant even though the height and crown diameter exceed the standards established for this purpose, because of its outstanding decorative features, as long as it is propagated from dwarfing rootstocks or is pruned regularly.

The hybrid GF001 (figures If and $1 g$ ) comes from crossing 'Galego Inerme Key' lime and Fortunella sp. (FTNL). The plant is short to medium in height, at $190 \mathrm{~cm}$, and has a dense ellipsoid crown (table I). Its leaves are elliptical and small (3.6 $\mathrm{cm}$ long by $1.9 \mathrm{~cm}$ wide) (table III). The fruits are also ellipsoid with a neck, and are light yellow when ripe (table III). It also has good decorative potential, indicated in the potted plant, landscaping and ornamental minifruit plant categories This hybrid results from crossing genotypes that have ornamental potential, the 'Galego Inerme Key' lime, which has a dense crown, small fruits and no spines, and Fortunella spp., which has small size and produces small yellowish fruits with smooth peel [8]. The ornamental use of fortunella plants is widespread, especially in Europe [19,20].

The hybrid RYG001 (figures $1 h$ and $1 i$ ) has small size, reaching only $160 \mathrm{~cm}$ in height. The crown is very voluminous and the thorn density is low (table I). During the entire 
Table III. Morphological traits of the fruits of 10 hybrid citrus seedlings with potential for ornamental use and their parentals. Values for quantitative descriptors are the mean of 20 replications followed by the standard errors.

\begin{tabular}{|c|c|c|c|c|c|c|c|c|c|c|c|c|c|}
\hline Hybrids & FR & FR & FR & FS & FS & FR & IF & $\mathrm{RF}$ & FS & AL & PU & $\mathrm{NF}$ & $\mathrm{AF}$ \\
\hline RYM011 & $77 \pm 0.21$ & $.61 \pm 0.18$ & $\mathrm{SP}$ & $\mathrm{CO}$ & $\mathrm{RO}$ & B & $\overline{\text { GR }}$ & $\overline{L Y}$ & & & $\overline{\text { GR }}$ & $3.40 \pm 0.5$ & -4 \\
\hline & & & $\mathrm{O}$ & M & & & GR & & & & E & & -4 \\
\hline & & & SP & $\mathrm{CO}$ & $\mathrm{NE}$ & & GR & & & & YE & & $2-4$ \\
\hline G & 40 & 3 & OT & MA & $\mathrm{NE}$ & & GR & & & & GR & & -4 \\
\hline GF001 & $0 \pm$ & $0 \pm$ & EL & MA & $\mathrm{NE}$ & $\mathrm{AB}$ & GR & LY & SM & WH & GR & 33 & $2-4$ \\
\hline RYG & NO & NO & NO & NO & NO & $\mathrm{NO}$ & NO & NO & NO & NO & NO & $\mathrm{NC}$ & $\mathrm{NO}$ \\
\hline M002 & $3.50 \pm$ & $2.70 \pm 0.1$ & EL & $\mathrm{AC}$ & TR & $\mathrm{AB}$ & GR & DY & SM & GR & GR & $1.20=$ & $2-4$ \\
\hline CMOC & 4.70 & $2.90 \pm$ & EL & MA & $\mathrm{NE}$ & $\mathrm{AB}$ & GR & LY & SM & WH & YE & 10 & $2-4$ \\
\hline C. & $\mathrm{O}$ & $\mathrm{NO}$ & $\mathrm{NO}$ & $\mathrm{NO}$ & NO & NO & NO & $\mathrm{NO}$ & NO & $\mathrm{NO}$ & $\mathrm{NO}$ & & $\mathrm{NO}$ \\
\hline RYSO & $30 \pm 0.11$ & $3.90 \pm 0.21$ & $\mathrm{OB}$ & TR & TR & $\mathrm{AB}$ & GR & OR & SM & OR & OR & $1.60 \pm$ & $2-4$ \\
\hline Parentals & FR & FR & FR & FS & FS & FR & IF & $\mathrm{RF}$ & FS & $\mathrm{AL}$ & $\mathrm{PU}$ & $\mathrm{NF}$ & $\mathrm{AF}$ \\
\hline RY0 & & $3.80 \pm 0$. & SP & $\mathrm{TR}$ & TR & & GR & DY & & W & YE & 5 & $2-4$ \\
\hline MCP & $5.45 \pm 0.38$ & $1.90 \pm 0.08$ & OT & OT & OT & $\mathrm{AB}$ & GR & YE & RG & GR & GR & .20 & $2-4$ \\
\hline GLINL & $3.46 \pm 0.18$ & $3.94 \pm 0.12$ & SP & RO & $\mathrm{CO}$ & $\mathrm{AB}$ & GR & LY & SM & WH & GR & 20 & $2-4$ \\
\hline FTNL & $2.65 \pm 0.12$ & $2.50 \pm 0.20$ & EL & RO & $\mathrm{CO}$ & $\mathrm{AB}$ & GR & OR & SM & WH & YE & $1.25 \pm 0.25$ & $2-4$ \\
\hline RPL & $5.80 \pm 0.22$ & $6.30 \pm 0.30$ & SP & TR & $\mathrm{CO}$ & $\mathrm{AB}$ & GR & OR & SM & WH & OR & $40 \pm 0.10$ & $2-4$ \\
\hline CSM & $3.35 \pm 0.20$ & $4.20 \pm 0.18$ & OB & OT & TR & $\mathrm{AB}$ & GR & OR & SM & OR & OR & $9.55 \pm 0.50$ & +6 \\
\hline SMM & $3.42 \pm 0.16$ & $4.30 \pm 0.30$ & OB & TR & TR & $\mathrm{AB}$ & GR & OR & SM & OR & OR & $9.20 \pm 0.75$ & +6 \\
\hline MCSH & $4.75 \pm 0.28$ & $1.73 \pm 0.18$ & OT & OT & OT & $\mathrm{AB}$ & GR & YE & RG & GR & GR & $1.20 \pm 0.25$ & $2-4$ \\
\hline
\end{tabular}

FRL = fruit length $(\mathrm{cm} ; \mathrm{FRD}=$ fruit diameter $(\mathrm{cm}) ; \mathrm{FRS}=$ fruit shape; FSB = shape of fruit base; FSA = shape of fruit apex; FRV = fruit variegation; IFC = immature fruit colo; RFC = ripe fruit colo; FST = fruit surface texture; $\mathrm{ALC}=$ albedo colo; $\mathrm{PUC}=$ pulp colo; $\mathrm{NFB}=$ number of fruits per bunc; $\mathrm{AFB}=$ average amount of fruits per bunc; ELL = ellipsoid; SPH = spheroi; OBL = obloi; OTH = other; TRU = truncat; ROU = rounded; $\mathrm{MAM}=$ mammiform; $\mathrm{ACU}=$ acute CON = conve; $\mathrm{NEC}=$ necke $; \mathrm{ABS}=$ absen; GRE = green; YEL= yellow; $\mathrm{LYE}=$ light yello; DYE = dark yellow; ORA = orang; RGH = rough; $\mathrm{SMO}=$ smoot; WHI = white; GRS = greenis; NOB = not observe; RYM011 $=($ RPL $\times$ YMCT- 005 $) \times$ MCP-011; RYM015 $=($ RPL $\times$ YMCT-005 $) \times$ MCP-015; RYM016 $=($ RPL $\times$ YMCT-005 $) \times$ MCP-016; GM002 = GLINL $\times$ MCP-002; GF001 = GLINL $\times$ FTNL-001; RYG001 $=($ RPL $\times$ YMCT-005 $) \times$ GLINL-001; RM002 $=$ RPL $\times$ MCSH-002; $\mathrm{CM} 002=\mathrm{CSM} \times \mathrm{MCP}-002 ; \mathrm{CM} 003=\mathrm{CSM} \times \mathrm{MCP}-003 ; \mathrm{RYS014}=(\mathrm{RPL} \times \mathrm{YMCT}-005) \times \mathrm{SMM}-014 ; \mathrm{RY} 005=\mathrm{RPL} \times \mathrm{YMCT} 005 ; \mathrm{MCP}$ = Microcitrus papuana Winter; GLINL = 'Galego Inerme Ke' lime [Citrus aurantiifolia (Christm.) Swingle; FTNL = Fortunella sp.; RPL= 'Rangpu' lime (C. limonia Osbeck; CSM = common 'Sunk' mandarin [C. sunki (Hayata) hort. ex Tanaka; SMM = 'Sunki Maravilh' mandari; YMCT = 'Yuma' citrange [C. sinensis (L.) Osbeck x Poncirus trifoliata (L.) Raf.; MCSH = Microcitrus Sydney hybrid [M. australis (A. Cunn. ex Mudie) Swingle $\times$ M. australasica (F. Muell.) Swingle].

evaluation period, this hybrid did not flower or produce fruits, an advantageous trait for planting in pots and for landscaping, mainly using the topiary technique.

The hybrid CM002 (figure 1j) is also a hybrid with strong ornamental potential. It has a short stature, reaching only $150 \mathrm{~cm}$ in height. The crown is very dense and has a large number of small spines (table I). It can be used to form hedges, and mainly in the construction of ornamental screens, because it responds well to topiary. Its leaves are small, measuring about $3.8 \mathrm{~cm}$ in length by $1.3 \mathrm{~cm}$ in width (table II). The fruits are small and ellipsoid, with mean width of $3.5 \mathrm{~cm}$ and diameter of $27 \mathrm{~cm}$, with attractive dark yellow color (table III). This genotype, together with the dwarfing rootstock HTR-010, a trifoliate hybrid developed by the CBP, is very small, measuring only $25 \mathrm{~cm}$ in height in its adult phase [21]. This behavior indicates that the association of ornamental scions with dwarfing rootstocks can enhance the decorative characteristics. This will be the subject of future study of the genotypes presented here.
We tested two crosses between CSM and MCP: CM002 (figures $1 \mathrm{k}$ and $1 \mathrm{l}$ ) and CM003 (figure $1 \mathrm{~m}$ ). Both are tall, having reached respective heights of $337 \mathrm{~cm}$ and $247 \mathrm{~cm}$. They both have dense ellipsoid crowns with branches starting at the base, giving them a cylindrical shape. They have long spines on the branches (table II and the leaves have similar size, shape and color (table II).

The hybrid CM002 produces small ellipsoidal fruits with neck, measuring $4.7 \mathrm{~cm}$ in length and $2.9 \mathrm{~cm}$ in diameter. When ripe, the fruits are light yellow, giving them high ornamental value. This hybrid can be used for the production of ornamental minifruits, as well as in the landscaping and hedge categories CM003 did not produce fruits or flowers during the study period, and is indicated for landscaping and hedges. The failure to produce fruits is probably due to the relatively long juvenile period of this genotype.

The hybrid RYS014 was the last of the 10 hybrids characterized (figures $1 n$ and 10 ). It presented a height of $222 \mathrm{~cm}$, with a spheroid crown and branches with dense and long spines 
Table IV. Morphological traits of the flowers of 10 hybrid citrus seedlings with potential for ornamental use and their parentals.

\begin{tabular}{lccccc}
\hline Hybrids & COF & AFL & PFI & ARO & ARP \\
\hline RYM011 & WHI & SOL, INF & AXI TER & FRU & PER \\
RYM015 & WHI & SOL, INF & AXI, TER & FRU, FLO & PER \\
RYM016 & WHI & SOL, INF & AXI, TER & FRU, FLO & PER \\
GM002 & WHI & SOL, INF & AXI, TER & FRU & PER \\
GF001 & WHI & SOL, INF & AXI, TER & FRU, FLO & NPE \\
RYG001 & NOB & NOB & NOB & NOB & NOB \\
RM002 & WHI & SOL, INF & AXI, TER & FRU, FLO & PER \\
CM002 & WHI & SOL, INF & AXI, TER & FRU, FLO & PER \\
CM003 & WHI & SOL, INF & AXI, TER & FRU & PER \\
RYS014 & WHI & SOL, INF & AXI, TER & FRU, FLO & PER \\
\hline Parentals & COF & AFL & PFI & ARO & ARP \\
\hline RY005 & WHI & SOL, INF & AXI, TER & FRU, FLO & NPE \\
MCP & WHI & SOL, INF & AXI, TER & FRU & NPE \\
GLINL & WHI & SOL, INF & AXI, TER & FRU, FLO & NPE \\
FTNL & WHI & SOL, INF & AXI, TER & FRU, FLO & NPE \\
RPL & WHI & SOL, INF & AXI, TER & FRU, FLO & PER \\
CSM & WHI & SOL, INF & AXI, TER & FRU & NPE \\
SMM & WHI & SOL, INF & AXI, TER & FRU, FLO & NPE \\
MCSH & WHI & SOL, INF & AXI, TER & FRU & NPE \\
\hline
\end{tabular}

$\mathrm{COF}=$ colour of open flower; $\mathrm{AFL}=$ arrangement of flowers; $\mathrm{PFI}=$ position of flower or inflorescence; $\mathrm{ARO}=$ aroma; $\mathrm{ARP}=$ aroma persistence; $\mathrm{WHI}=$ white; $\mathrm{NOB}=$ not observed; $\mathrm{SOL}=$ solitary; $\mathrm{INF}=$ inflorescence; $\mathrm{AXI}=$ axillary; $\mathrm{TER}=$ terminal; FRU $=$ fruits; FLO = flowers; NPE $=$ not persistent; PER $=$ persistent; RYM011 $=($ RPL $\times$ YMCT-005 $) \times$ MCP-011; RYM015 $=($ RPL $\times$ YMCT- 005 $) \times$ MCP-015; RYM016 $=($ RPL $\times$ YMCT-005 $) \times$ MCP-016; GM002 = GLINL $\times$ MCP-002; GF001 = GLINL $\times$ FTNL-001; RYG001 $=($ RPL $\times$ YMCT-005 $)$ $\times$ GLINL-001; RM002 = RPL $\times$ MCSH-002; CM002 = CSM $\times$ MCP-002; CM003 = CSM $\times$ MCP-003; RYS014 = $($ RPL $\times$ YMCT-005 $)$ $\times$ SMM-014; RY005 = RPL $\times$ YMCT-005; MCP = Microcitrus papuana Winters; GLINL = 'Galego Inerme Key' lime [Citrus aurantiifolia (Christm.) Swingle]; FTNL = Fortunella sp.; RPL= 'Rangpur' lime (C. limonia Osbeck); CSM = common 'Sunki' mandarin [C. sunki (Hayata) hort. ex Tanaka]; SMM = 'Sunki Maravilha' mandarin; YMCT = 'Yuma' citrange [C. sinensis (L.) Osbeck $\times$ Poncirus trifoliata (L.) Raf.]; MCSH = Microcitrus Sydney hybrid [M. australis (A. Cunn. ex Mudie) Swingle $\times$ M. australasica (F. Muell.) Swingle].

(table I). It is the most unique of the hybrids studied, with elliptical leaves measuring $10.2 \mathrm{~cm}$ in length and $3.7 \mathrm{~cm}$ in width (table II). Its fruits are micro-tangerines, very similar to the male parent, 'Sunki Maravilha' mandarin. They have dark orange color, with average length of $3.3 \mathrm{~cm}$ and diameter of 39 and are highly decorative (table III). It has good ornamental potential, for planting in pots, landscaping and production of minifruits.

Except for the hybrid RM002, about which no information was obtained about flowering, and hybrids RYG001 and CM003, the other genotypes studied showed precocity regarding start of flowering and hence fruit production, which occurred at ages between three and four years, in comparison with most other citrus seedlings, which take at least seven years to reach maturity [22]. The early start of flowering is a very important trait, because flower and fruit production are desirable qualities of ornamental plants. The practice of grafting using buds obtained from mature branches in the matrix of each ornamental hybrid is especially favored if using dwarfing rootstocks that induce early flowering, because this enhances the agronomic manifestation of this attribute besides enabling substantial reduction of the size of the scion-rootstock combination.

\subsection{CTV-tolerance evaluation}

In regard to $\mathrm{CTV}$ tolerance, the results were promising with $40 \%$ of the hybrids showing resistance, $40 \%$ very tolerant and only $20 \%$ were very intolerant (table $V$ ). This evaluation was performed based on ELISA test and the density of grooves in the branches.

Despite the presence of the virus in the hybrids RYM016, RYG001, CM002 and RYS014, they were classified as very tolerant to CTV as the plants were free of grooves (table $V$ ).

In the hybrid GF001 (figures $1 f$ and $1 g$ ) the ELISA tests detected the presence of CTV in the tissues and very dense grooves on the branches, indicating high intolerance to the virus, a characteristic also found in its female parent, $C$. aurantiifolia, a species notably sensitive to the CTV [23]. The hybrid RM002 was also highly intolerant to CTV, having high intensity of grooves in its branches. This behavior of both hybrids indicates the need for protection with mild CTV strains.

This kind of study is fundamental for the adoption of these new hybrids by growers since this disease is really important to the citrus crop. Therefore, the most effective way to control the disease is the use of resistant or tolerant varieties and preimmunization with mild strains of the virus. 

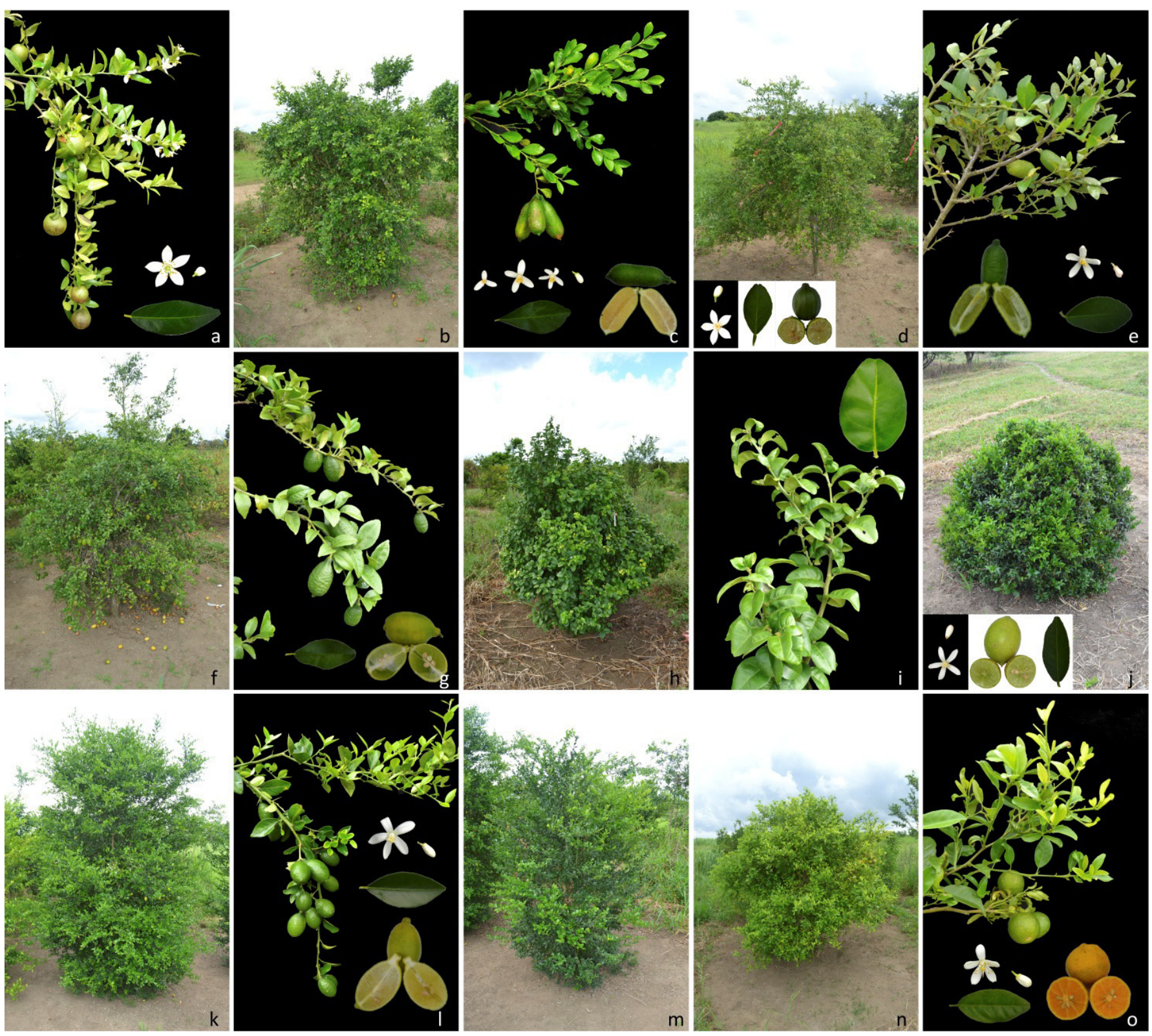

Figure 1. Plants and details of the branches, fruits, leaves and flowers of 10 hybrid seedlings with potential for ornamental use. Citrus Breeding Program of Embrapa Cassava \& Fruits. (a) RYM011 = (RPL $\times$ YMCT-005) $\times$ MCP-011. (b) $-(\mathrm{c})$ RYM015 $=($ RPL $\times$ YMCT-005) $\times$ MCP-015. (d) RYM016 = (RPL $\times$ YMCT-005) $\times$ MCP-016. (e) GM002 = GLINL $\times$ MCP-002. (f) $-($ g) GF001 = GLINL $\times$ FTNL-001. $($ h $)-(\mathrm{i})$ RYG001 $=(\mathrm{RPL} \times$ YMCT-005) $\times$ GLINL-001. (j) RM002 $=\mathrm{RPL} \times \mathrm{MCSH}-002 .(\mathrm{k})-(\mathrm{l}) \mathrm{CM} 002=\mathrm{CSM} \times \mathrm{MCP}-002 .(\mathrm{m}) \mathrm{CM} 003=\mathrm{CSM} \times \mathrm{MCP}-003$. n-o RYS014 = $($ RPL $\times$ YMCT-005) $\times$ SMM-014.

\section{Conclusion}

The hybrids evaluated presented substantial morphological variability that distinguished them from each other. Their traits qualify them for use as ornamental plants The genus Microcitrus has potential for use in crosses aimed at obtaining hybrids with potential ornamental use. The 10 hybrids assessed can be recommended for use for landscaping, and in association with dwarfing rootstocks, as potted plants. Eight can be indicated for use to form hedges and eight for use as ornamental minifruit plants. Of the 10 hybrids evaluated for resistance to the citrus tristeza virus (CTV), four were resistant, three very tolerant and two very intolerant.

Acknowledgements. The authors acknowledge the support of Conselho Nacional de Desenvolvimento Científico e Tecnológico - CNPq (472492/2011-0), and Coordenação de Aperfeiçoamento de Pessoal de Nível Superior (CAPES) for the scholarships granted. We also thank the researcher Orlando Sampaio Passos, curator of the Citrus Active Germplasm Bank of Embrapa Cassava \& Fruits, and the anonymous reviewers for their valuable suggestions. 
Table V. Presence and intensity of grooves and indirect ELISA test results for citrus tristeza virus (CTV) in 10 hybrid seedlings with potential for ornamental use.

\begin{tabular}{lccc}
\hline Hybrids & $\begin{array}{c}\text { Detection of CTV } \\
\text { via indirect ELISA }\end{array}$ & $\begin{array}{c}\text { Mean presence and intensity } \\
\text { of grooves caused by CTV }\end{array}$ & Reaction to CTV \\
\hline RYM011 & & $1.03 \pm 0.03$ & Resistant \\
RYM015 & + & $1.20 \pm 0.10$ & Resistant \\
RYM016 & + & $1.00 \pm 0.00$ & Very tolerant \\
GM002 & + & $1.00 \pm 0.00$ & Resistant \\
GF001 & + & $3.90 \pm 0.10$ & Very intolerant \\
RYG001 & + & $1.20 \pm 0.10$ & Very tolerant \\
RM002 & + & $3.50 \pm 0.50$ & Very intolerant \\
CM002 & & $1.10 \pm 0.05$ & Very tolerant \\
CM003 & + & $1.10 \pm 0.05$ & Resistant \\
RYS014 & + & $1.00 \pm 0.00$ & Very tolerant \\
\hline
\end{tabular}

RYM011 = $($ RPL $\times$ YMCT-005 $) \times$ MCP-011; RYM015 $=($ RPL $\times$ YMCT- 005 $) \times$ MCP-015; RYM016 $=($ RPL $\times$ YMCT-005 $) \times$ MCP-016; GM002 = GLINL $\times$ MCP-002; GF001 = GLINL $\times$ FTNL-001; RYG001 $=($ RPL $\times$ YMCT-005 $) \times$ GLINL-001; RM002 $=$ RPL $\times$ MCSH 002; CM002 = CSM $\times$ MCP-002; CM003 = CSM $\times$ MCP-003; RYS014 = $($ RPL $\times$ YMCT-005 $) \times$ SMM-014; MCP $=$ Microcitrus papuana Winters; GLINL = 'Galego Inerme Key' lime [Citrus aurantiifolia (Christm.) Swingle]; FTNL = Fortunella sp.; RPL= 'Rangpur' lime (C. limonia Osbeck); CSM = common 'Sunki' mandarin [C. sunki (Hayata) hort. ex Tanaka]; SMM = 'Sunki Maravilha' mandarin; YMCT = 'Yuma' citrange [C. sinensis (L.) Osbeck $\times$ Poncirus trifoliata (L.) Raf.]; MCSH = Microcitrus Sydney hybrid [M. australis (A. Cunn. ex Mudie) Swingle $\times$ M. australasica (F. Muell.) Swingle].

${ }^{1}$ Means obtained from analysis of ten branches by three evaluators based on rating scale described by Meissner et al. [16].

\section{References}

[1] FAO - FAOSTAT. Agricultural statistics database. World Agricultural Information Center, 2015, Rome. http://faostat.fao. org/site/567/default.aspx\#ancor. Accessed 4 Jan 2015.

[2] Swingle W.T., The botany of Citrus and its wild relatives, in: Reuther W., Webber H.J., Batchelor L.D. (Eds.), The citrus industry. University of California, Berkeley CA, 1967.

[3] Suryawanshi J.A.S., An overview of Citrus aurantium used in treatment of various diseases, Afr. J. Plant Sci. 5 (2011) 390395.

[4] Azam M., Song M., Fan F., Zhang B., Xu Y., Xu C., Chen K., Comparative analysis of flower volatiles from nine Citrus at three blooming stages, Int. J. Mol. Sci. 14 (2013) 22346-22367.

[5] Navarra M., Mannucci C., Delbò M., Calapai G., Citrus bergamia essential oil: from basic research to clinical application, Frontier Pharmacol. 6 (2015) 1-7.

[6] Del Bosco S.F., The use for ornamental purposes of an ancient Citrus genotype, Acta Hortic. 598 (2003) 65-67.

[7] Mazzini R.B., Pio R.M., Morphological characterization of six citrus varieties with ornamental potential, Rev. Bras. Frutic. 32 (2010) 463-470.

[8] Santos A.R.A., Souza E.H., Souza F.V.D., Fadini M., Girardi E.A., Soares Filho W.S., Genetic variation of Citrus and related genera with ornamental potential, Euphytica 205 (2015) 503520 .

[9] Junqueira A.H., Peetz M.S., Panorama socioeconômico da floricultura no Brasil, Rev. Bras. Hortic. Orn. 17 (2011) 101-108.

[10] Souza E.H., Souza F.V.D., Costa M.A.P.C., Costa Junior, D.S., Santos-Serejo J.A., Amorim E.P., Ledo C.A.S., Genetic variation of the Ananas genus with ornamental potential, Gen. Res. Crop Evol. 59 (2012) 1357-1376.

[11] Garnsey S.M., Lee R.F. Tristeza., in: Whiteside J.O., Garnsey S.M., Timmer L.W. (Eds.) Compendium of citrus diseases APS Press, St. Paul, MN, 1989.

[12] Salibe A.A., Sobrinho J.T., Müller G.W., Sinopse de conhecimentos e pesquisas sobre a laranja 'Pêra' Laranja 23 (2002) 231-245.

[13] Moreno P., Ambrós S., Albiach-Martí M.R., Guerri J., Peña L., Citrus tristeza virus: a pathogen that changed the course of the citrus industry, Mol. Plant. Pathol. 9 (2008) 251-268.

[14] IPGRI - International Plant Genetic Resources Institute. Descriptors for Citrus. Rome: IBPGR (1999). http://www. bioversityinternational.org/e-library/publications/detail/ descriptors-for-citrus-emcitrusem-spp/. Accessed 8 May 2013.

[15] Meissner Filho P.E., Soares Filho W.S., Velame K.V.C., Diamantino E.P., Diamantino M.S.A.S., Reaction of hybrid rootstocks to Citrus tristeza virus, Fitopatol. Bras. 27 (2002) 312-315.

[16] Koenig R., Indirect ELISA methods for the broad specificity detection of plant viruses, J. Gen. Virol. 55 (1981) 53-62.

[17] Hartmann H.T., Kester D.E., Davies Junior F.T., Geneve R.L., Plant propagation: principles and practices Prentice Hall, New Jersey, USA, 2002.

[18] Gandía M., Conesa A., Ancillo G., Gadea J., Forment J., Pallás V., Floresb R., Duran-Vila N., Moreno P., Guerri J., Transcriptional response of Citrus aurantifolia to infection by Citrus tristeza virus, Virology 367 (2007) 298-306.

[19] Saunt J., Citrus varieties of the world: an illustrated guide, Sinclair International, Norwich, England, 1990. 
[20] Pinto M.J., Faustino J.J., Duarte A.M., Aplicação de retardadores de crescimento em citrinos ornamentais, Acta Hortic. 17 (1997) 89-95.

[21] Fadini M., Girardi E.A., Santos M.G., Gesteira A.S., Passos O.S., Souza F.V.D., Soares Filho W.S., Secion and rootstock combinations for ornamental Citrus in containers, in: Book of Abstracts of the XII International Citrus Congress, Valencia, Spain, 2012.
[22] Soares Filho W.S., Cunha Sobrinho A.P., Passos O.S., Souza A.S., Melhoramento genético, in: Cunha Sobrinho A.P., Magalhães A.F.J., Souza A.S., Passos O.S., Soares Filho W.S. (Eds.), Cultura dos citros, Embrapa, Brasília, Brazil 2013.

[23] Spiegel-Roy P., Goldschmidt E.E., Biology of Horticultural Crops: Biology of Citrus, Cambridge University Press, Cambridge, England, 1996.

Cite this article as: Alanna Rachel Andrade dos Santos, Everton Hilo de Souza, Michaella Fadini, Fernanda Vidigal Duarte Souza, Cristiane de Jesus Barbosa, Eduardo Augusto Girardi, Walter dos Santos Soares Filho. Selection of CTV-tolerant citrus hybrids for ornamental use. Fruits 71 (2016) 389-398. 